A N N A LES

UNIVERSITATIS MARIAE CURIE-SKŁODOWSKA

LUBLIN - POLONIA

VOL. LXVI, 1

SECTIO G

2019

Uniwersytet Wrocławski

MAREK MACIEJEWSKI

marek.maciejewski@uwr.edu.pl

ORCID: 0000-0002-5296-1394

\title{
Dietrich Eckart. U organizacyjnych \\ i ideowych podstaw nazizmu (1919-1923)
}

Dietrich Eckart. At the Organizational and Ideological Foundations of Nazism

(1919-1923)

I.

Geneza i początki niemieckiego narodowego socjalizmu (jego organizacji, działalności, propagandy i ideologii) nie zostały jeszcze wyczerpująco opracowane naukowo, choć na temat różnych aspektów i przejawów nazizmu powstało na świecie mnóstwo publikacji i wciąż pojawiają się nowe rozprawy. Wobec tego stawiam sobie za zadanie badawcze właśnie ukazanie wycinka wczesnych dziejów tego zjawiska politycznego (od zarania NSDAP w 1919 r. do puczu monachijskiego w 1923 r.), ale tylko w odniesieniu do kwestii znaczenia i roli w ówczesnym rozwoju narodowego socjalizmu Dietricha Eckarta (1868-1923). Co prawda, jego działalność i poglądy zostały już częściowo przedstawione przez niektórych zagranicznych autorów, lecz są one nadal mało znane $\mathrm{w}$ Polsce ${ }^{1}$. Tymczasem $\mathrm{z}$ różnych względów zasługują na pełniejsze omówienie. Okazuje się bowiem, że ten mieszkający w Monachium niedoszły lekarz, parający się poezją, tłumaczeniami oraz publicystyką, odznaczający się dobrymi manierami i towarzyską ogładą, a także mający dość rozległe kontakty polityczne, wywarł trudny do przecenienia wpływ na kształtowanie się w tamtym okresie nazizmu, i to na dwóch ważnych płaszczyznach: organizacyjnej oraz ideologicznej. Niektórzy niemieccy autorzy skłonni są nawet uznawać - nieco przesadnie -

1 Tylko częściowe ich omówienie - głównie z punktu widzenia doktrynalnego - zawiera moja monografia Od piwiarnianego klubu do organizacji wywrotowej. Nazizm w latach 1919-1924, Torun 2005 , s. 274 i n. 
Eckarta (bardziej nawet niż samego Adolfa Hitlera) za swego rodzaju fundatora narodowego socjalizmu w Niemczech, a w każdym razie przypisywać mu część zasług w jego rozwoju w kilku pierwszych latach powojennych. Według cenionego badacza tej problematyki, Georga Franza-Willinga, był on nawet ,duchowym ojcem ruchu hitlerowskiego"’2. Jak się jeszcze przekonamy, Eckart rzeczywiście wyraźnie zaznaczył swoją obecność w procesie tworzenia się organizacyjnych i ideowych zrębów nazizmu. Jego oddziaływanie na kształtowanie się narodowego socjalizmu uwidoczniło się w szczególnie dobitny sposób w sferze formowania się w pierwszej połowie lat 20. XX stulecia antysemickiego oblicza nazizmu.

Niezbyt liczni w swej grupie badacze początków narodowego socjalizmu (tzw. Vorbewegung) na ogół zgodnie - i całkowicie słusznie - uwypuklają zwłaszcza znaczny wpływ tego poety i dziennikarza na dopiero stawiającego pierwsze kroki w polityce Hitlera. Eckart stał się wtedy wręcz głównym mentorem przyszłego wodza Trzeciej Rzeszy, i to nawet do tego stopnia, że uczył Hitlera poprawnej niemczyzny, podsuwał mu literaturę wartą przeczytania, rozwijał tkwiące w nim zdolności oratorskie, zachęcał go do publicznych wystąpień, dbał nawet o jego strój i maniery, pomagał mu finansowo oraz - co nie mniej ważne - zapoznał go z niektórymi przedstawicielami niemieckich elit. Można zaryzykować twierdzenie, że poniekąd „stworzył” Hitlera jako polityka, choć nie był jedyną osobą, która wycisnęła na nim wyraźne piętno. Jeszcze przed wybuchem I wojny światowej Hitler przesiąknął bowiem w Wiedniu nacjonalistyczno-antysemicko-rasistowską ideologią (nazywaną volkistowską), wysoko ceniąc sobie niektórych jej twórców (m.in. Karla von Luegera i Georga von Schönerera) $)^{3}$. Wszystko to okazało się nader przydatne, wręcz niezbędne w rozwoju kariery Hitlera. Czy nie zaistniałby on w sferze publicznej bez takiego wsparcia i pomocy właśnie ze strony Eckarta - trudno jednoznacznie stwierdzić. Po I wojnie światowej znaleźli się przecież jeszcze inni protektorzy Hitlera, jak np. mający pewne wpływy w armii Ernst Röhm, późniejszy dowódca nazistowskich oddziałów szturmowych (SA), zamordowany zresztą w 1934 r. na polecenie wodza Trzeciej Rzeszy. Żaden z nich nie okazał się jednak tak ważny wtedy dla Hitlera, jak Eckart, który nie odznaczał się - co warto podkreślić - ani szczególną inteligencją, ani nadzwyczajnymi zdolnościami propagandowymi ${ }^{4}$.

2 G. Franz-Willing, Die Hitlerbewegung. Der Ursprung 1919-1922, Hamburg-Berlin 1962, s. 126. Podobnie: W. Maser, Der Sturm auf die Republik. Frühgeschichte der NSDAP, Stuttgart 1973, s. 180; W. Görlitz, H.A. Quint, Adolf Hitler. Eine Biographie, Stuttgart 1953, s. 145.

3 Szerzej zob. M. Maciejewski, O przestankach i źródtach światopoglądu Adolfa Hitlera, „Studia nad Autorytaryzmem i Totalitaryzmem” 2013, t. 35, z. 1, s. 105 i n.; idem, Wiedeński okres w życiu Adolfa Hitlera w ujęciu Brigitte Hamann i Augusta Kubizka, „Studia nad Autorytaryzmem i Totalitaryzmem" 2017, t. 39, z. 3, s. 69 i n.

4 Podobnie uważają autorzy najnowszych publikacji. Zob. m.in. P. Valode, Hitler i tajne stowarzyszenia, Warszawa 2010, s. 67 i n.; J.H. Tyson, Hitler's Mentor: Dietrich Eckart. His Life, Time and Millieu, Bloomington 2008, s. 24 i n.; P. Craftword, Dietrich Eckart. Master of the Occult and Hitler's Mentor, London 2013, s. 21 i n. 
Nie był wszakże takim niedouczonym parweniuszem, jak Hitler. Nie sądzę, by należało uznać go - jak uczynił to Konrad Heiden - jedynie za takiego człowieka, który „chciałby zostać posiadaczem nieruchomości, zarabiającym piórem na wygodne życie i cieszącym się poważaniem dozorcy swego domu"s. Eckart miał bowiem znacznie większe ambicje życiowe. W dodatku był obdarzony silnym charakterem, a jego sztuki teatralne (Familienväter, Der Froschkönig, Lorenzaccio) cieszyły się popularnością w stolicy Bawarii, mimo że nie zasługiwały na miano wybitnych ${ }^{6}$, gdyż z punktu widzenia walorów literackich nie przedstawiały większej wartości. Pewne uznanie zyskał sobie także jego przekład Peer Gynta Henrika Ibsena (1912). Co ważniejsze, ze względu na tematykę tego artykułu, obyty w środowiskach monachijskiej bohemy i miejscowego establishmentu Eckart cechował się sporą intuicją polityczną. W opinii Ralfa Maxa Engelmanna miał on nieczęstą umiejętność „stawiania na właściwego konia" i raczej rzadko mylił się w swych osobistych wyborach $^{7} . \mathrm{Z}$ jakichś powodów postawił m.in. właśnie na Hitlera, i to chyba nie tylko dlatego, że łączyło ich ze sobą ideowe pokrewieństwo.

Uzasadnione wydaje się w związku z tym pytanie, na które odpowiedź może przyczynić się do wyjaśnienia roli Eckarta w życiu Hitlera: Czy coś szczególnie zaintrygowało tego publicystę $w$ nieokrzesanym jeszcze i niepewnym siebie Hitlerze, co skłoniło go do wspierania jego poczynań już na samym początku lat 20.? Być może spowodowała to ówczesna nieporadność Hitlera w połączeniu z neurastenią i zainteresowaniem ezoteryzmem, ariozofią oraz okultyzmem (cechującym także Eckarta czy Alfreda Rosenberga) ${ }^{8}$, a równocześnie skrywane, wygórowane aspiracje polityczne tego byłego uczestnika wojny światowej. Zagubiony po jej zakończeniu, Hitler znajdował się wówczas na takim etapie życia, w którym usilnie poszukiwał pewnych wzorców i autorytetów osobowych. Niewątpliwie kimś takim okazał się dla niego - wprawdzie tylko na kilka lat po 1918 r. - Eckart. Raz jeszcze powtórzę: tak czy inaczej ten publicysta w niemałym stopniu wykreował Hitlera, nadając mu pewien intelektualny i polityczny szlif. Nie dziwią zatem opinie części uczonych, w tym wybitnego, choć kontrowersyjnego znawcy nazizmu Ernsta Noltego, według których Eckart należał do wąskiego grona „,autentycznych nauczycieli i mistrzów” przyszłego przywódcy Niemiec (obok

5 K. Heiden, A History of National Socialism, London 1934, s. 7.

6 Na trwałe jednak nie wszedł do historii literatury niemieckiej. Na próżno byłoby szukać jego nazwiska w podręcznikach do nauki tego przedmiotu, np. u Curta Hohoffa (Flügel der Zeit. Deutsche Gedichte 1900-1950, Frankfurt am Main 1956).

7 R.M. Engelmann, Dietrich Eckart and the Genesis of Nazism, Ann Arbor 1971, s. 18.

8 Część autorów dopatruje się w tych metafizycznych skłonnościach Adolfa Hitlera, Alfreda Rosenberga czy Heinricha Himmlera jednej z istotnych przesłanek kształtowania się zrębów nie tylko rasistowskiej, lecz także antychrześcijańskiej, niemal pogańskiej ideologii NSDAP. Zob. F. Ribadeu-Dumas, Tajemne zapiski magów Hitlera, Warszawa 1992, passim; N. Goodrick-Clarke, Okultystyczne źródła nazizmu. Tajne kulty aryjskie oraz ich wplyw na ideologię nazistowską. Ariozofowie z Austrii i Niemiec 1890-1935, Warszawa 2001, passim. 
m.in. Ericha Ludendorffa, Gottfrieda Federa i Ernsta Röhma) u zarania nazizmu9 . Już po śmierci tego publicysty Hitler określił go w Mein Kampf (1924) jako osobę, która jak „nikt inny w Niemczech” poświęciła „swe życie ku przebudzeniu naszego narodu w literaturze, poezji, myśli, aż w końcu w czynie"10. Dodam, że o niewielu innych swych współtowarzyszach Hitler - bynajmniej nieskory do pochwał - wypowiadał się tak jednoznacznie pozytywnie. Niedługo przed objęciem urzędu kanclerza Rzeszy miał w ciepłych słowach wyrazić się o swym współtowarzyszu z pierwszej połowy lat 20.: „Mój dobry przyjaciel Dietrich Eckart, co by on powiedział, gdyby mógł nas teraz widzieć i to, czego dokonaliśmy. Dałbym wiele, żeby mógł być tutaj”"11. Znając sympatię wodza Trzeciej Rzeszy do tego dziennikarza, nazistowscy autorzy prześcigali się od $1933 \mathrm{r}$. w pochwałach dla niego. W opublikowanej już po zdobyciu władzy w Niemczech książce Alberta Reicha Eckart został uznany za „wybitnego szermierza ruchu narodowego"12. Na jego cześć odbywały się w Trzeciej Rzeszy uroczyste spotkania i prelekcje, a od 1933 r. zaczęła się ukazywać odrębna seria wydawnicza „Der Eckart-Kreis”, w której zamieszczali swe utwory reżimowi poeci. W 1938 r. dedykowano pamięci Eckarta pierwszy tom serii pt. Wiersze narodu (Gedichte des Volkes) ${ }^{13}$. Naziści mieli oficjalne powody, by doceniać tego poetę i publicystę, m.in. za to, że był autorem wiersza Deutschland, erwache!, zawierającego wezwanie do walki z tzw. systemem weimarskim. Obok Horst-Wesel-Lied utwór ten stał się bojową pieśnią członków SA. Hasło Eckarta dotyczące ,przebudzenia Niemiec” już na początku lat 20. Hitler włączył do swej propagandy. Należy zaznaczyć, że Eckart nigdy nie zagroził przywódczym aspiracjom Hitlera, lecz przeciwnie - wydatnie przyczynił się do ich rozbudzenia i ukierunkowania. Poza tym, w odróżnieniu do Hitlera, nie dążył do osiągnięcia większych sukcesów w polityce, zadowalał się rolą patrona i doradcy. Jak się wydaje, jego ambicją było stać się ideowym guru dla sił nacjonalistyczno-rasistowskich.

Nie bez znaczenia dla powstania i początkowego rozwoju narodowego socjalizmu (najpierw tylko w samej Bawarii) okazały się związki Eckarta z niewielką,

9 E. Nolte, Der Faschismus in seiner Epoche. Die Action française. Der italienische Faschismus. Der Nationalsozialismus, München 1962, s. 56, 398. Zob. H. Auerbach, Hitlers politische Lehrjahre und die Münchener Gesellschaft, ,Vierteljahrshefte für Zeitgeschichte“ 1977, Nr. 1, s. 18; A. Bullock, Hitler i Stalin. Żywoty równoległe, Warszawa 1994, s. 90-91.

10 A. Hitler, Mein Kampf, München 1933, s. 178.

11 Podaję za: K. Luedecke, I Knew Hitler, London 1938, s. 489. Zob. także: A. Zoller, Hitler privat. Erlebnisbericht einer Geheimsekräterin, Düsseldorf 1949, s. 118.

12 A. Reich, Dietrich Eckart - ein deutscher Dichter und Vorkämpfer der völkischen Bewegung, München 1933, s. 7 i n. Eckart znalazł się również na ,zaszczytnej liście” nazistowskich autorów w urzędowym opracowaniu E. Ungera Das Schrifttums des Nationalsozialismus von 1919 bis. 1. Januar 1934 (Berlin 1934, s. 46 i n.).

13 H. Böhme, Gedichte des Volkes. Dietrich-Eckat-Band (Vom Jahr 1 bis zum Januar 5 des Dritten Reiches), München 1938. 
lecz wpływową w Monachium, bazującą na okultyzmie i germańskich mitach organizacją nacjonalistyczno-rasistowską o nazwie Thule-Gesellschaft (TG). To założone pod koniec I wojny światowej przez Rudolfa von Sebottendorffa stowarzyszenie można nawet uznać za ugrupowanie prenazistowskie. W jego nielicznych szeregach karierę polityczną rozpoczęło bowiem w latach 1919-1920 kilku późniejszych prominentów NSDAP. Oprócz Eckarta byli to m.in. Alfred Rosenberg, Hans Frank, Julius Streicher, Rudolf Hess i Karl Harrer. TG objęło politycznym patronatem poprzedniczkę NSDAP - miniaturową Deutsche Arbeiterpartei, w której pierwsze kroki jako agitator stawiał od września 1919 r. Hitler, zachęcony do publicznej aktywności przez Eckarta i kilka innych osób z kręgów nacjonalistycznych. Eckart jeszcze przed Hitlerem wstąpił do tej partii, starając się ukierunkować ją ideologicznie. Głównie za pośrednictwem tego dziennikarza przyszły wódz Trzeciej Rzeszy mógł zapoznać się z (odpowiadającą zresztą jego światopoglądowi) propagandą TG wymierzoną w Żydów. Ideologowie związani z von Sebottendorffem uważali tę nację i rasę za „śmiertelnych wrogów” Niemiec, postulując w związku z tym pozbycie się Żydów z Rzeszy ${ }^{14}$. Co prawda, nie opowiadali się za fizyczną eksterminacją tej ludności, lecz przede wszystkim za wprowadzeniem takich restrykcji, które skłoniłyby ją do emigracji, by w ten sposób „uchronić rasowych Niemców przed żydowskimi wpływami”. Nawiązując do germańskiej mitologii, TG chętnie posługiwało się znakiem swastyki jako swym godłem. Antysemickie hasła służyły tej organizacji do krytyki powstałego pod koniec 1918 r. w Niemczech ustroju demokracji parlamentarnej. Utworzoną na gruzach cesarstwa Hohenzollernów tzw. republikę weimarską postrzegano jako „,̇ydowską formę państwa” niezgodną z „niemieckim duchem narodowym”.15. Jak inne ugrupowania spod znaku völkische, tak i TG chętnie powielało nacjonalistyczne hasło o „ciosie zadanym Niemcom w plecy” (Dolchstoss) pod koniec I wojny światowej przez państwa Ententy, Żydów i inne ,wrogie” siły polityczne, pozostające rzekomo ze sobą w zmowie przeciwko Rzeszy. Łatwo się domyśleć, że hasłem tym ochoczo szermowali m.in. nazistowscy demagodzy, a wśród nich Eckart i Hitler. Podczas wydarzeń rewolucyjnych w Bawarii w 1919 r. omawiane stowarzyszenie próbowało - wraz z innymi siłami antykomunistycznymi - kilkakrotnie dokonać przewrotu przeciwko tamtejszej republice rad.

Eckart i niektórzy przyszli naziści (m.in. Joseph Goebbels, Gottfried Feder, Alfred Rosenberg, Julius Streicher) udzielali się także w o wiele bardziej licznym od TG i powstałym później od niego ugrupowaniu nacjonalistycznym

14 Postulaty te przejęli od założonego w 1912 r. Germanen-Orden. Zob. H. Gilbhard, Die Thule-Gesellschaft. Vom okkulten Mummenschanz zum Hakenkreuz, München 1994, s. 78 i n.; D. Rose, Die Thule-Gesellschaft. Legende-Mythos - Wirklichkeit, Tübingen 2000, s. 35 i n.

15 R.H. Phelps, "Before Hitler Came": Thule Society and Germanen Orden, "Journal of Modern History" 1963, No. 3, DOI: https://doi.org/10.1086/243738, s. 247; G. Schubert, Die Anfänge der nationalsozialistischen Aussenpolitik 1919-1923, Berlin 1961, s. 30. 
Deutschvölkischer Schutz- und Trutzbund (DSTB). Również ono miało w swej uporczywie głoszonej propagandzie wiele haseł antysemickich, reprezentowało w tych sprawach poglądy zbliżone do organizacji von Sebottendorffa. Jeden z najbardziej znanych przedstawicieli DSTB, Theodor Fritsch, często formułował chwytliwy i niezwykle nośny w kręgach nacjonalistycznych postulat: „Niemcy Niemców” (Deutschland den Deutschen). Przedstawiając Żydów jako „tyranów nowoczesnego życia" (kapitalistów, demokratów, komunistów itp.), konstruował negatywny, pozbawiony cech ludzkich stereotyp członków tej rasy. Usilnie starał się bowiem dowieść, że Żydzi zostali stworzeni przez Boga jedynie na podobieństwo małpy ${ }^{16}$. Jako podrzędna i gatunkowo odrębna rasa nie powinni więc być traktowani humanitarnie, gdyż po prostu na to nie zasługują. Można niemal z pewnością przyjąć, że antysemickie i rasistowskie rojenia von Sebottendorffa czy Fritschego okazały się inspirujące dla Hitlera oraz innych narodowych socjalistów. Przywódca Trzeciej Rzeszy nawet zaliczał Fritscha do swych duchowych nauczycieli ${ }^{17}$. Na początku lat 20. więcej uczył się jednak od Eckarta, który za cel postawił sobie wprowadzenie Hitlera do tzw. wielkiej polityki, zapoznając go m.in. z legendarnym z okresu I wojny światowej generałem Ludendorffem, jednym z głównych późniejszych uczestników wydarzeń podczas próby puczu nazistowskiego w Monachium z listopada 1923 r. Mało tego, Eckart umożliwił Hitlerowi nawiązanie kontaktów z przedstawicielami przemysłowców niemieckich, zwłaszcza z branży metalurgicznej (jak Emil Kirdorf, August Thyssen), co zaowocowało udzieleniem przez niektórych z nich finansowego wsparcia NSDAP, szczególnie potrzebnego na początku lat 20 . Ten bywający w tzw. szerokim świecie dziennikarz stał się również gwarantem pożyczki udzielonej przez dowództwo Reichswehry kierownictwu tej partii na zakup jej sztandarowego czasopisma „Völkischer Beobachter”. Już choćby powyższe informacje wskazują na spore zasługi Eckarta dla Hitlera i NSDAP.

Na tym wszakże nie koniec jego wkładu w kształtowanie się wczesnego narodowego socjalizmu. W marcu 1920 r. zamierzał on bowiem zabrać Hitlera do Berlina specjalnie w tym celu wynajętym samolotem, by zapoznać go ze współprzywódcą trwającego wtedy, nieudanego antyrepublikańskiego puczu, nacjonalistą Wolfgangiem Kappem, którego uważał za utalentowanego polityka ${ }^{18}$. Upatrywał

16 R.H. Phelps, Theodor Fritsch und der Antisemitismus, „Deutsche Rundschau“ 1961, Nr. 5, s. 442; G.L. Mosse, Kryzys ideologii niemieckiej. Rodowód intelektualny Trzeciej Rzeszy, Warszawa 1970, s. 190.

17 Z mniejszym uznaniem Hitler odnosił się natomiast do von Sebottendorffa, choć ten starał się przekonywać o swej szczególnej roli w powstaniu organizacji nazistowskiej. Zob. R. von Sebottendorff, Bevor Hitler kam. Urkundliches aus der Frühzeit der nationalsozialistischen Bewegung, München 1934, passim.

18 Eckart wychwalał Kappa na łamach wydawanego przez siebie pisma „Auf gut deutsch” (1920, Nr. 12/12, 1920, s. 146). 
w nim nawet ówczesnego Johanna W. von Goethego, oczywiście nie w literaturze, lecz w sprawach polityczno-militarnych. Kapp odwdzięczył się za to publicyście udzieleniem mu (wraz z kilkoma innymi bogatymi osobami) niemałej subwencji na wydawanie przez niego antyrepublikańskiego i antysemickiego pisma „Auf gut deutsch”. Było ono „oczkiem w głowie” Eckarta, który miał o sobie wysokie mniemanie jako o dziennikarzu. W rzeczywistości był raczej przeciętnym publicystą, jak wielu innych volkistowskich propagandystów. Mimo to pragnął uczynić z „Auf gut deutsch" wiodący periodyk w Niemczech, a nawet ,propagandową forpocztę" walki z tzw. systemem weimarskim. Nie on jeden wśród tamtejszych nacjonalistów uważał, że likwidacja demokracji parlamentarnej w Rzeszy - w połączeniu z eliminacją tzw. żydostwa (Judentum) - powinna być najważniejszym zadaniem „narodowo myślących Niemców”19. Tym bardziej był niezadowolony, że nie udało się doprowadzić do spotkania Hitlera z Kappem w Berlinie, co poczytywał za swoją osobistą porażkę. Mimo to po powrocie do Monachium Eckart wraz z Hitlerem starali się nakłonić władze bawarskie, z premierem Gustavem von Kahrem na czele, do poparcia wywrotowej aktywności Kappa i podjęcia działań wymierzonych w Żydów. W tym samym celu prowadzili rozmowy z wpływowym bawarskim politykiem chłopskim Georgem Heimem, któremu składali obietnice udziału w przyszłym rządzie nazistowskim, jeśli by poparł dążenia do likwidacji republikańskich władz Rzeszy w wyniku akcji zbrojnej sił nacjonalistycznych. Choć zabiegi te nie przyniosły zamierzonego skutku, to spowodowały wzrost zainteresowania organizacją nazistowską i samym Hitlerem ze strony Kahra. Częściowo pod wpływem Eckarta zaczął on doceniać rosnące znaczenie organizacji nazistowskiej w układzie sił politycznych w Bawarii. Warto nadmienić, że premierowi tego kraju związkowego zachwalał już w 1920 r. ,aktywność i prężność” ówczesnych narodowych socjalistów były dowódca Hitlera w armii kapitan Karl Mayr ${ }^{20}$. Jego także należy uznać za swego rodzaju protektora młodego Hitlera, choć mniej ważnego od Eckarta.

Nie sposób pominąć wreszcie roli tego dziennikarza w kreowaniu wizerunku Hitlera jako wybitnego i otoczonego niemal kultem przywódcy nazistów na początku lat 20. Gdy pod koniec lipca 1921 r. Hitler stanął na czele NSDAP, nadając jej charakter organizacji opartej na zasadzie wodzostwa (Führerprinzip), Eckart bez wahania znalazł się w gronie nazistów z zaangażowaniem wspierających przemiany strukturalne $\mathrm{w}$ tej partii ${ }^{21}$. Wtedy okazał się wręcz entuzjastą

19 Zob. J.H. Tyson, op. cit., s. 26 i n.; P. Craftword, op. cit., s. 52 i n.; M. Plewnia, Auf dem Weg zu Hitler. Der völkischer Publizist Dietrich Eckart, Bremen 1970, s. 34 i n.

20 D. Stegmann, Zwischen repression und Manipulation. Konservative Machtteilen und Arbeiter- und Angestelltenbewegung 1910-1918, „Archiv für Sozialgeschichte“ 1971, Bd. 12, s. 413 414. Zob. I. Kershaw, Hitler. 1889-1935. Hybris, Poznań 2001, s. 115-116.

${ }^{21}$ Szerzej o procesie przejmowania władzy nad NSDAP przez Hitlera zob. M. Maciejewski, Wódz i jego drużyna. Poczatki ksztaltowania się władzy i autorytetu Adolfa Hitlera wśród nazistów, „Studia nad Faszyzmem i Zbrodniami Hitlerowskimi” 2010, t. 32, s. 93 i n. 
nadania Hitlerowi, jako przewodniczącemu NSDAP, przywódczych uprawnień; wielokrotnie podkreślał jego nieprzeciętne zdolności polityczne, do rozwoju których sam się zresztą przyczynił. Dodam, że pod koniec życia bardziej krytycznie odnosił się do rządów Hitlera nad narodowymi socjalistami ${ }^{22}$. To właśnie Eckart w znacznej mierze przyłożył się już w $1921 \mathrm{r}$. do upowszechnienia w szeregach NSDAP określenia: „Nasz wódz Adolf Hitler”. O nowym przewodniczącym tej partii pisał wówczas z dużym uznaniem: „Żaden człowiek nie może tak bezinteresownie, ofiarnie, rzetelnie służyć sprawie, jak naszej poświęca się Hitler. Nikt nie jest również tak świadom celu i czujny" ${ }^{\prime 23}$. Częściowo zasługą samego Eckarta, a częściowo innych propagandystów z NSDAP (m.in. Hermanna Essera, Alfreda Rosenberga, Rudolfa Hessa) było doprowadzenie do narastania wśród nazistów w następnych kilku latach kultu Hitlera, który z czasem przerodził się w mit Führera. Z okazji rocznicy jego urodzin (20 kwietnia 1923 r.) Eckart ułożył wiersz wychwalający, a nawet gloryfikujący atrybuty wodza NSDAP: „Czyż nie ma już siły, która za nasze zwycięstwa ręczy? / Serca w górę! Kto chce widzieć, ten widzi! / Tu jest siła, przed którą ciemność ucieka!"’24. W lecie 1923 r. Eckart wyraził, jak się wydaje, szczere przekonanie, że ,jeśli los wyznaczył w ogóle jakiegoś człowieka w celu uratowania Niemiec, to tym człowiekiem jest tylko Adolf Hitler"25. Popierający Hitlera w rozwoju jego kariery politycznej Eckart opracował już w połowie 1920 r. - być może z myślą właśnie o nim - wizerunek ,prawdziwego wodza" narodu niemieckiego. Przyszłego przywódcę przedstawiał jako osobę charyzmatyczną: nieżonatą, gotową do największych poświęceń dla ojczyzny oraz odznaczającą się ,wewnętrzną siłą, duchową głębią i dobrym sercem”26.

Na koniec pierwszej części artykułu należy wspomnieć jeszcze o pełnym poparciu udzielonym przez Eckarta uczestnikom nieudanego puczu monachijskiego. Już ciężko chory na serce, będący na łożu śmierci (zmarł pod koniec 1923 r.) i ukrywający się przed bawarską policją (z powodu zniesławienia prezydenta Rzeszy Friedricha Eberta i czekającego go z tego powodu procesu sądowego), Eckart nie mógł wziąć czynnego udziału w tych wydarzeniach. Bardzo zresztą

22 Eckart czynił Hitlerowi zarzuty $\mathrm{z}$ powodu jego zaangażowania w związki z kobietami (m.in. z żoną Ernsta Hanfstaengla), co miało go odciągać od spraw partyjnych i politycznych. Zob. E. Hanfstaengl, Zwischen Weissem und Braunem Haus. Memoiren eines politischen Aussenseiters, München 1970, s. 109.

${ }^{23}$ „Völkischer Beobachter“ 1921, Nr. 93 (7. Dezember). Zob. także artykuły w tym czasopiśmie, m.in. 1922, Nr. 18 (4. März), 1922, Nr. 38 (13. Mai), 1922, Nr. 67 (23. August). Odsyłam ponadto do pracy I. Kershawa Mit Hitlera. Wizerunek a rzeczywistość III Rzeszy (Zakrzewo 2009).

24 Podaję za: H. Böhme, Rufe in das Reich. Die heldische Dichtung von Langemarck bis zur Gegenwart, Berlin 1934, s. 177. Według A. Rosenberga (Blut und Ehre. Ein Kampf für deutsche Wiedergeburt. Reden und Aufsätze 1919-1933, München 1939, s. 12) nazwisko Hitlera już w 1923 r. przybrało „mityczne brzmienie”.

25 Za: M. Plewnia, op. cit., s. 46.

26 „Auf gut deutsch“' 1920, Nr. 7, s. 102. 
tego żałował ${ }^{27}$. Z uwagą starał się jednak śledzić przebieg puczu, słownie zachęcając jego uczestników, a zwłaszcza Hitlera i Ludendorffa, do walki aż do zwycięstwa. Niewykluczone, że emocjonalne zaangażowanie Eckarta po stronie zamachowców przyspieszyło jego śmierć, a na pewno przyczyniło się do znacznego pogorszenia stanu zdrowia tego publicysty. Niedługo przed śmiercią (19 grudnia 1923 r.) wyraził on nadzieję, że ruch nazistowski będzie się nadal rozwijać, mimo że otrzymał „ciężki cios” w postaci delegalizacji NSDAP i innych podobnych organizacji nacjonalistycznych po próbie akcji wywrotowej w stolicy Bawariii ${ }^{28}$. Autentycznie ubolewając nad niepowodzeniem akcji wywrotowej z listopada 1923 r., starał się wciąż wierzyć w zdolności polityczne Hitlera do odbudowy jego partii, która znalazła się wówczas w stanie rozpadu i niewiele wskazywało na to, że się z niego kiedykolwiek podniesie. Mimo to Eckart do końca życia gotów był - jak tylko mógł - wspierać Hitlera; przepowiadał mu świetlaną przyszłość polityczną, ale przestrzegał również przed popełnianiem błędów w tej dziedzinie (mogącym wynikać zwłaszcza z poczucia nadmiernej pewności siebie) ${ }^{29}$. Wydaje się, że z mentora wodza NSDAP, górującego nad Hitlerem intelektem i wpływowymi znajomościami, Eckart ostatecznie przeistoczył się - zaledwie w ciągu trzech lat - w jego wielbiciela, a nawet podwładnego. Graniczące z pewnością przeświadczenie Eckarta z końca 1923 r., że Hitler i jego partia będą odnosić jeszcze sukcesy w Niemczech, okazało się trafne. Odnośne oczekiwania Eckarta zaczęły się spełniać, choć dopiero na początku lat 30., gdy NSDAP zyskiwała coraz większą popularność społeczną w kolejnych wyborach parlamentarnych. Wiara publicysty w zdolności i karierę Hitlera, ujawniająca się niemal od samego początku ich znajomości, zapewne nie była jednak bezpodstawna. Omówione przykłady aktywności Eckarta dobitnie świadczą o tym, że stał się on już na samym początku lat 20 . zaangażowanym i ideowym nazistą, mimo że nigdy nie pełnił żadnej odpowiedzialnej funkcji w NSDAP.

II.

Jak już wzmiankowałem, oprócz zasług w tworzeniu organizacyjnych zrębów narodowego socjalizmu Eckart wydatnie przyczynił się także do ukształtowania się podstaw jego ideologii. Jego wpływ na nią uwidocznił się przede wszystkim w sprawach dotyczących określenia na samym początku lat 20. stosunku NSDAP do Żydów. Można niemal jako pewnik przyjąć, że aktywiści tej partii - z Hitlerem

27 M. Plewnia, op. cit., s. 112.

28 Archiwum Institut für Zeitgeschichte München, Zespół Mikrofilm-Abteilung (MA) - 745, nfol. Odsyłam też do patetycznego wiersza Eckarta z tego okresu, wychwalającego odwagę i bezkompromisowość Hitlera. Zob. R. Euringer, Dietrich Eckart. Leben eines deutschen Dichters, Hamburg 1935, s. 33.

29 P. Craftword, op. cit., s. 146 i n. 
na czele - w znacznej mierze właśnie Eckartowi „zawdzięczali” swój antysemityzm. Niektórzy z nich okazali się nawet większymi, bardziej zaciekłymi od tego dziennikarza przeciwnikami Żydów. Oczywiście nie był on jedynym, lecz tylko jednym z wielu inspiratorów wrogości nazistów do tej nacji. Antysemityzm czerpali oni z różnych źródeł ideowych, zwłaszcza od dość licznego grona twórców wspomnianego volkizmu, rozwijającego się jako nurt doktrynalny już od schyłku XIX w. Eckart miał jednak tę przewagę nad innymi volkistami spoza NSDAP i sprzed jej powstania, że sam był współorganizatorem tej partii i osobiście dokładał starań, by nadać jej antysemicki charakter. Jego poglądy polityczne w zasadzie niczym szczególnym nie różniły się - co należy podkreślić - od zapatrywań innych volkistów. Wszyscy powielali bowiem szablon haseł utartych od dziesięcioleci w tej nacjonalistyczno-antysemicko-rasistowskiej ideologii. Pod tym względem Eckart nie był wcale oryginalny w swych koncepcjach, choć wniósł pewne własne postulaty antysemickie. Niewątpliwie mieściły się one w szeroko rozumianym kanonie volkistowskiej frazeologii politycznej. O tym, że ten publicysta przyczynił się do zaszczepienia lub rozwinięcia wśród narodowych socjalistów wrogości wobec Żydów - choć nie tak zajadłej, jak np. w przypadku Juliusa Streichera - przekonani są niemal wszyscy bezstronni badacze poglądów politycznych Eckarta, m.in. Margareta Plewnia, Ralf Max Engelmann, Peter Craftword i Joseph Howard Tyson ${ }^{30}$. Jak się jeszcze przekonamy, Eckart był niezupełnie konsekwentny w swych poglądach na Żydów. Z jednej strony krytykował tę nację, na ogół unikając w odniesieniu do niej pojęcia „,rasa”. Z drugiej zaś dostrzegał w niej pewne cechy niemal pozytywne. Antysemityzm narastał w tym nacjonalistycznym dziennikarzu stopniowo i konsekwentnie. Eckart stał się przeciwnikiem Żydów w zasadzie dopiero około 1914 r., gdy zaczął uważać, że tzw. kwestia żydowska (Judenfrage) stanowi ,główny problem ludzkości” od zarania jej dziejów, wymagający ,jakiegoś rozwiązania”31. Jeszcze nie wiedział wtedy, na czym miałoby ono konkretnie polegać. Nie wykluczał wszakże podjęcia w tej sprawie „odpowiednich środków zaradczych”, raczej niezbyt radykalnych. W 1919 r. dowodził: „Nic na świecie nie pozostanie mroczne, jeśli ktoś zdoła rzucić światło na ich [Żydów - M.M.] tajemnicę"32. Jej wyjaśnienie i wskazanie na płynące $\mathrm{z}$ niej zagrożenia oraz na sposoby zaradzenia im Eckart traktował jako podstawowy cel swego pisma „Auf gut deutsch”, które ukazywało się od końca 1918 r. do maja 1921 r. To właśnie na jego łamach znalazł się jeszcze przed powstaniem NSDAP postulat uczynienia pełnoprawnymi obywatelami Rze-

30 Na publikacje tych autorów powołuję się we wcześniej sporządzonych przypisach do tego artykułu.

31 Jeszcze w tragikomedii Familienväter (1904) ukazywał Żydów jako ludzi na ogół nieszczęśliwych i zasługujących na litość. Dopiero konflikt Eckarta z pewnym Żydem - dyrektorem jednego $\mathrm{z}$ teatrów w Berlinie - miał spowodować narastanie w nim antysemityzmu. Zob. G. Franz-Willing, op. cit., s. 127.

32 „Auf gut deutsch“1919, Nr. 4, s. 35. 
szy tylko osób krwi niemieckiej (Blutgenossen) ${ }^{33}$. Tym samym takimi obywatelami nie powinni być Żydzi, co zostało następnie w 1920 r. podkreślone w programie partii nazistowskiej, opracowanym zresztą przy wydatnym udziale Eckarta. O antysemickiej wymowie „Auf gut deutsch” świadczyły również zamieszczane w nim rozmaite paskudne karykatury Żydów jako fabrykantów, bankierów, lichwiarzy itp.

Do ukształtowania się antysemickich poglądów Eckarta mogła przyczynić się przyjęta przez niego podczas I wojny światowej idea chaosu - celowo wywoływanego i niszczącego ludzkość - jako czynnika mającego determinować rozwój dziejów. Znamienne, że owa figura myślowa została użyta przez tego publicystę niejako na przekór panującej wtedy w Rzeszy atmosferze entuzjazmu z powodu wybuchu wojny, która miała - jak powszechnie uważano - przynieść zwycięstwo Niemcom, podsycając imperialne nastroje. Eckart zdawał się nie podzielać tego optymizmu nacjonalistów, choć sam uważał się za patriotę i popierał militarne cele cesarstwa wilhelmińskiego. Już w 1917 r. przestrzegał jednak przed grożącymi Niemcom niebezpieczeństwami, zwłaszcza ze strony ,światowego spisku żydowskiego", który miał dążyć do unicestwienia Rzeszy. Warto dodać, że nie tylko on wyznawał w Niemczech (w tym burzliwym okresie zmagań militarnych) tego rodzaju pesymistyczną w swej wymowie historiozofię. Szczególny wyraz znalazła ona w krytycznych wobec cywilizacji mieszczańskiej i wszelkich wartości Zachodu koncepcjach Oswalda Spenglera, głoszącego katastroficzną wizję przyszłości ludzkości ${ }^{34}$. Również ten domorosły uczony z Monachium wskazywał na destrukcyjną rolę m.in. Żydów w procesie upadku dawnych cywilizacji. Jeszcze bardziej wrogo był nastawiony do Żydów Eckart, mimo że nie rozpatrywał dziejów ludzkości aż tak filozoficznie, jak Spengler. Jeszcze podczas I wojny światowej, a nie tylko po jej zakończeniu (jak czyniła to większość volkistów), oskarżał on Żydów (będących ponoć w zmowie z państwami Zachodu) o bezwzględną realizację swej „demonicznej żądzy panowania nad światem”. Już w 1916 r. utrzymywał, wieszcząc zbliżający się triumf sił wrogich Niemcom za granicą i w kraju: „Żyd stara się życie spożyć we wszystkim, co może władzy przysporzyć" ${ }^{35}$. Za przejawy występowania wszechobecnej idei chaosu - w celu podporządkowania sobie świata przez Żydów - uważał klęskę militarną Rzeszy pod koniec 1918 r., upadek cesarstwa Hohenzollernów, ustanowienie ustroju republikańskiego w Niemczech itp. W wydarzeniach tych dopatrywał się skutków działania ulotnego i ukrytego, ale siejącego wszędzie spustoszenie „ducha żydowskiego” (jüdischer Geist). To za sprawą tego publicysty zostało w programie NSDAP z 1920 r. zawarte wielo-

33 A. Rosenberg, Dietrich Eckart. Ein Vermächtnis, München 1935, s. 52.

34 Spengler przedstawił ją niedługo po I wojnie światowej w dziele, nad którym pracował od kilku lat jako nad swoim filozoficznym credo: Der Untergang des Abendlandes. Umrisse einer Morphologie der Weltgeschichte (Bd. 1-2, München 1922-1923).

35 D. Eckart, Der Heilige und der Narr. Gedanken über das Chaos unserer Zeit, „Unser Vaterland“"1916, Nr. 1, s. 13. 
znaczne sformułowanie, że partia ta zwalcza ,żydowsko-materialistycznego ducha w nas i poza nami" ${ }^{36}$. Do tej kwestii jeszcze nawiążę w niniejszym artykule. W tym miejscu należy natomiast zauważyć, że Eckart - jak wielu innych volkistów - wyznawał w sprawach żydowskich spiskową teorię dziejów. Pozostał jej zresztą wierny do końca swego życia, nieustannie poszukując dowodów na potwierdzenie słuszności swoich przekonań. Jak twierdził m.in. w rozmowach z Hitlerem na samym początku lat 20.: „We wszystkim, co nas otacza, prawie zawsze Żydzi maczają swoje palce, choć my o tym często nie wiemy"37. Przyjmując taki tok rozumowania, Eckart wysnuwał z niego typowe dla ówczesnego nacjonalistycznego sposobu myślenia wnioski. Wszystko to, co spotkało Niemcy pod koniec 1918 r. i w latach następnych, miało być bowiem rezultatem zwycięstwa żydowskiego „zła” (niemoralność, materializm, pazerność, bezduszność, obskurantyzm, bezwzględność itp.) nad niemieckim „dobrem” (dyscyplina, porządek, pracowitość, prawość, poświęcenie) $)^{38}$.

Przeciwstawienie jednego rodzaju postaw drugiemu typowi zachowań ludzkich służyło zarówno Eckartowi, jak i innym nacjonalistycznym ideologom niemieckim po I wojnie światowej za podstawę do rozważań nad istotą tzw. żydostwa. Zespołu cech określanych tym mianem nie przypisywał on tylko osobom narodowości żydowskiej, lecz także tym wszystkim, którzy symbolizowali owo zło, nawet jeśli nie byli Żydami w znaczeniu antropologicznym czy rasowym. Eckart nie przywiązywał zresztą większej wagi (inaczej niż Hitler) do kwestii rasowych, choć nie negował ich znaczenia. Niewątpliwie bardziej interesowały go kwestie osobowościowe i to z tego punktu widzenia starał się oceniać Żydów, wyróżniając dwie kategorie tych ludzi. Ci drudzy Żydzi, czyli niepodpadający pod kryterium wyłącznie rasowe (antropologiczne) czy religijne, mieli być nawet gorsi od pierwszych (tylko na pozór „właściwych” Żydów), gdyż ich żydostwo wynikało z własnego świadomego wyboru, zdeterminowanego przez czynniki psychologiczne i intelektualne, a nie z samego faktu urodzenia. Tego rodzaju niby-Żydów jako szczególnie groźnych i podstępnych, bo celowo przynależących do tej kategorii osób, Eckart określał średniowiecznym terminem Judentzern, czyli jako popleczników i patronów Żydów. Przestrzegał, że z tych względów są oni jeszcze bardziej bezwzględni i zaborczy od autentycznych Żydów, gdyż pragną okazać się bardziej, ,żydowscy”. Za takich Żydów z wyboru, a nawet $\mathrm{z}$,perwersyjnego umiłowania siebie samych”, uważał np. tych Niemców (republikanów, pacyfistów, socjalistów itp.), którzy przyczynili się do upadku cesarstwa Hohenzollernów, a także np. do upowszechnienia się ,rozwiązłego stylu ży-

36 G. Feder, Das Programm der NSDAP und seinen weltanschaulichen Grundgedanken, München 1933, s. 17.

37 M. Plewnia, op. cit., s. 67. Zob. także: P. Craftword, op. cit., s. 122.

38 „Auf gut deutsch“ 1918, Nr. 1, 1918, s. 3; 1919, Nr. 3, s. 83; 1919, Nr. 16, s. 253; 1920, Nr. 22, s. 352 . 
cia" poprzez propagowanie homoseksualizmu i libertynizmu. W odróżnieniu od rasowo lub kulturowo pojmowanych Żydów jako materialistów czy hedonistów Aryjczycy mieli być „urodzonymi idealistami i metafizykami”39. Eckart piętnował więc przede wszystkim nie tyle samych Żydów, ile liczne przejawy „zżydzenia” (Verjudung) w Niemczech i innych krajach. W 1919 r. wyraził pogląd: „Nie chodzi o zwalczanie Żydów jako ludzi, lecz o zwalczanie żydowskiego ducha"40. Innymi słowy, duch ten jako rodzaj postawy życiowej, mentalności i moralności wydawał się temu dziennikarzowi jeszcze bardziej niebezpieczny - bo trudny do rozpoznania i wyplenienia - od samych Żydów jako narodu. Urastał on nawet w jego poglądach do rangi czynnika określającego istotę tzw. kwestii żydowskiej.

W sprawie stosunku do Żydów Eckart przynajmniej częściowo różnił się od swego ucznia - Hitlera. Przyszły wódz Trzeciej Rzeszy nie okazał się pod tym względem bezkrytycznym obiorcą zapatrywań swego mentora, choć starał się go w niejednym słuchać i naśladować. Antysemityzm Eckarta mógł mu się jednak wydawać zbyt „miękki” czy nazbyt ,akademicki”, a także za mało rasistowski. Co prawda, Hitler nie przewidywał na początku lat 20. fizycznej eksterminacji Żydów (taką ewentualność zaczął rozważać dopiero w znacznie późniejszym okresie), lecz już wtedy opowiadał się za bardziej radykalnymi sposobami rozwiązania „kwestii żydowskiej” niż tylko za zwalczaniem owego zżydzenia. Jak się wydaje, wrogość do Żydów jako takich (czyli rasowych Żydów) była w mniejszym stopniu - w porównaniu z Hitlerem - eksponowana przez Eckarta. Co więcej, publicysta ten nie odmawiał Żydom prawa do istnienia jako narodu i kultywowania własnych tradycji czy wyznawania religii mojżeszowej. Uważał nawet, że przynależą oni do „organizmu ludzkości, jak określone bakterie do ciała człowieka"41. Eckart potrafił się zdobyć na raczej niezwykły dla antysemity gest, mianowicie na uznanie za pozytywną cechę Żydów m.in. ich „bezprzykładnej niezmienności charakteru”. Ubolewał, że brakowało jej Niemcom. Podobnie jak niegdyś Fryderyk Nietzsche, tak i Eckart krytykował ten naród, a przynajmniej jego znaczną część, za skłonność do filisterstwa, gnuśności czy pragnienie dostatku, upatrując w nich zaprzeczenie idei nadczłowieka (Übermensch). Nie przeszkadzało mu to - jak już pisałem - wychwalać niektóre pozytywne cechy Niemców. Co do antysemityzmu Eckarta można przypuszczać, że do przekonania Hitlera nie trafiały jeszcze inne, niezbyt zajadłe czy nienawistne w swej wymowie poglądy tego dziennikarza na temat Żydów. Na przykład według niego możliwe, a nawet poniekąd naturalne i oczywiste, powinno być współżycie - swego rodzaju modus vivendi - Żydów i Niemców w jednym państwie. W ogóle nie wyobrażał

39 „Auf gut deutsch” 1920, Nr. 30/34, s. 388 i n.

40 „Auf gut deutsch” 1919, Nr. 6, s. 95. W pracy Das Judentum in und ausser uns z 1918 r. pisał: „Wir müssen also die Juden unter uns schon als notwendiges Übel hinnehmen, wer weiss wie viele Jahrtausende noch”. Podaję za: A. Rosenberg, Dietrich Eckart..., s. 217.

41 „Auf gut deutsch“ 1919, Nr. 27, s. 421. 
sobie tego natomiast Hitler, z góry odrzucając taką ewentualność jako niedorzeczną i szkodliwą dla czystości rasy germańskiej. W opinii Eckarta owo współistnienie powinno układać się na zasadzie kontrastu między „wodą” i „ogniem” czy między „światłem” i „ciemnością”, opierając się na nieustannej rywalizacji tych dwóch narodów. Dodam, że przywódca NSDAP już w latach 20. opowiadał się za „wydaleniem” (Entfernung) Żydów z Rzeszy ${ }^{42}$. Wracając do Eckarta, wcale nie był on jednak pewny zwycięstwa Niemców w konkurencji z Żydami, choć tych drugich uważał pod wieloma względami za gorszych od pierwszych. Wszelako nie odmawiał im ani sprytu czy inteligencji, ani konsekwencji w działaniu czy wytrwałości. Uznawał więc Żydów, zwłaszcza zaś zakamuflowanych nosicieli „ducha żydowskiego", poniekąd za godnych przeciwników Niemców, a tym samym za trudnych do zwalczania. Na pewno nie przewidywał jednak w odniesieniu do Żydów w obu znaczeniach tego słowa zastosowania metod fizycznej likwidacji, co najwyżej uwzględniał podjęcie pewnych restrykcji czy jakichś represji w celu zwalczania ,żydowskiego ducha". Nacje żydowską i niemiecką chętnie porównywał ze sobą również na zasadzie „,zupełnego przeciwieństwa” między kobietą i mężczyzną ${ }^{43}$. Uosobieniem męskiego charakteru przypisywanego przez Eckarta Niemcom miał być Faust, a kobiecego charakteru Żydów - Mefisto. Zestawienie Żyda jako szatana z postacią Niemca-Fausta prowadziło tego publicystę do rozważań nad przesłankami likwidacji wspomnianego ducha chaosu w świecie.

Przyczyny zamętu determinującego dzieje od samego początku gatunku ludzkiego, w tym relacje między Żydami i Niemcami, skłonny do filozoficznych rozważań Eckart upatrywał w panującym dualizmie ducha (idei) i rzeczywistości (materii). Należy zaznaczyć, że w swych przepojonych metafizyką poglądach na ten temat wcale nie był on ani odkrywczy, ani oryginalny. Kwestią dwoistości bytów zajmowano się - przypomnę - już w starożytności (przede wszystkim Platon i Arystoteles), średniowieczu (m.in. św. Tomasz z Akwinu) i czasach nowożytnych (Kartezjusz i inni filozofowie). Brak dowodów, by stwierdzić, że Eckart znał koncepcje tych intelektualistów. Nie można jednak uznać tego za wykluczone, należał bowiem do osób oczytanych, wykazywał zainteresowanie sprawami egzystencjalnymi, często z pogranicza wiedzy tajemnej i paranaukowej. Dyskurs o tych dwóch sferach ontologicznych - na ogół dość powierzchowny i nastawiony na cele propagandowe, czyli głównie na krytykę

42 Szerzej zob. M. Maciejewski, Z nienawiści do Żydów. Rozważania nad głównym komponentem światopogladu Adolfa Hitlera, [w:] Medycyna w cieniu nazizmu, red. M. Michalak, K.B. Głodowska, Poznań 2015.

43 W tej kwestii Eckart wzorował się na poglądach Żyda-odszczepieńca, o zapatrywaniach volkistowskich, Ottona Weiningera, który w pracy Geschlecht und Charakter (1905), prawdopodobnie znanej także Hitlerowi, dychotomię między kobietą i mężczyzną podniósł do rangi głównej zasady wszechświata. Zob. B. Hamann, Wiedeń Hitlera. Lata nauki pewnego dyktatora, Warszawa 2013, s. 291 i n. 
republiki weimarskiej - pojawiał się również w wywodach niektórych bliskich światopoglądowo Eckartowi ideologów volkistowskich, wywodzących się z kręgów tzw. rewolucyjnego konserwatyzmu w Niemczech po I wojnie światowej, zwłaszcza w kontekście formułowanych przez nich wizji nowej Rzeszy, opisywanej (poniekąd w odpowiedzi na idee Trzeciego Rzymu) w kategoriach eschatologicznych, nacjonalistycznych, antydemokratycznych i autorytarnych. Jeden z reprezentantów tego nurtu doktrynalnego, pisarz polityczny Arthur Moeller van den Bruck, upowszechnił nawet już w 1923 r. pojęcie „Trzecia Rzesza” jako wyraz uwieńczenia procesu dziejowego Niemiec, trwającego od Pierwszej Rzeszy (średniowiecznej), poprzez Drugą Rzeszę (wilhelmińską), do tej wyczekiwanej i ostatecznej Rzeszy ${ }^{44}$. Jak wiadomo, ten nośny propagandowo termin został skwapliwie wykorzystany i uznany za własny przez nazistów z Hitlerem na czele. Należy podkreślić, że jeszcze przed Moellerem van den Bruckiem określeniem drittes Reiches posługiwał się Eckart. Już w 1919 r. dowodził on: „Nigdzie na ziemi inny naród nie byłby bardziej niż nasz predestynowany do stworzenia Trzeciej Rzeszy! Veni creatoe spiritus!"45. Mająca stanowić kulminację niemieckich dziejów przyszła wspaniała Rzesza powinna - jak spodziewał się ten publicysta - ostatecznie doprowadzić do przezwyciężenia dualizmu, a właściwie dychotomii między duchem i materią (przede wszystkim więc między Żydami i Niemcami), a w miejsce owej dwoistości i odrębności wprowadzić „jedność obu bytów w każdej dziedzinie życia niemieckiego narodu”. W celu opisania tego procesu dziejowego, czyli ostatecznego zapanowania światłości i potęgi ludzkiego charakteru nad ciemnością i diabelską mocą, Eckart niekiedy nawiązywał do postaci wspomnianego Fausta $\mathrm{z}$ utworu cenionego przez siebie poety Goethego. Za intelektualistę wieszczącego w sposób literacki nadejście Trzeciej Rzeszy jako finalnego tworu społeczno-kulturowo-państwowego Eckart uważał jednak - rzecz znamienna - norweskiego dramaturga Ibsena ${ }^{46}$.

Wskazówek dotyczących narodzin tej Rzeszy Eckart doszukiwał się zwłaszcza w przetłumaczonym przez siebie dziele tego pisarza Peer Gynt z 1867 r. Należy zaznaczyć, że głównemu bohaterowi tego utworu nazistowski publicysta nadał odmienne niż w oryginale cechy charakteru. Niejako na siłę starał się z niego uczynić wzór godny naśladowania przez Niemców. W przekładzie Eckarta Peer Gynt symbolizował bowiem wolę władzy, która miała stanowić „,ultima ratio jego nienasyconości” w dążeniu do panowania i doskonałości ${ }^{47}$.

44 A. Moeller van den Bruck, Das dritte Reich, Hamburg 1931. Odsyłam też do pracy S. Lauryssensa Człowiek, który wymyślit Trzecia Rzeszę (Wrocław 2000), w której są omówione kulisy powstania tego terminu-symbolu oraz nieformalnej nazwy państwa niemieckiego w latach 1933-1945.

45 „Auf gut deutsch“1919, Nr. 12, s. 73.

46 R. Engert, Henrik Ibsen als Verkünder des Dritten Reiches, Leipzig 1921, s. 26.

47 A. Rosenberg, Dietrich Eckart..., s. 183. Zob. także: R. Lembert, Dietrich Eckart. Ein Künder und Kämpfer des Drittes Reiches, München 1934, s. 16. Podobny wizerunek bohatera - jako 
Pod tym względem wizerunek bohatera dramatu Ibsena przypominał i Fausta Goethego, i „nadczłowieka” Nietzschego. O wpływie amoralnych i nihilistycznych koncepcji tego filozofa mogło świadczyć ujmowanie przez Eckarta istoty tzw. niemieckości (Deutschtum) - wyrażonej w postawie Peer Gynta - jako pragnienia rzeczy niemożliwych (Wille zum Unmöglichen) do osiągnięcia przez inne narody. Zdaje się nie ulegać wątpliwości, że interpretacja dzieła Ibsena przez Eckarta trafiała do przekonania Hitlera. Głoszonej już na początku lat 20. przez przywódcę NSDAP koncepcji prymatu Niemiec w świecie publicysta ten nadał pseudofilozoficzną nadbudowę, która opierała się na wierze w „boską wielkość" człowieka jako wybitnej jednostkii" ${ }^{48}$. Być może zainspirowany właśnie przez Eckarta Hitler - sam uważający się za kogoś wyjątkowego - odniósł owo przekonanie przede wszystkim do Niemców, wiążąc je z rasistowską argumentacją o wyjątkowości i wielkości Aryjczyków. Eckart postrzegał ten problem w sposób nie tak szeroki narodowo, jak przywódca NSDAP. Dla tego dziennikarza siedliskiem i ostoją osób o cechach tak Peer Gynta, jak i Fausta byli głównie niemieccy chłopi. To w nich upatrywał warstwę najmniej skażoną przez ,żydowską cywilizację przemysłową”, bo opierającą się nie na „typowo miejskim chaosie i pogoni za zyskiem", lecz na mistycznym związku z przyrodą, a nawet z kosmosem. Nadmienię, że jeszcze przed Eckartem wartości niemieckiego chłopstwa jako najbardziej zdrowej i rasowo czystej części narodu eksponowali w swych poglądach niektórzy ideolodzy volkistowscy z końca XIX w., a już w okresie Trzeciej Rzeszy zwłaszcza Walther Darrè ${ }^{49}$. Eckart przeciwstawiał wyidealizowany przez siebie etos chłopski ponoć właściwym dla Żydów cechom interesowności i przebiegłości. Krytykując żydowski materializm i intelektualizm, zapewniał w 1921 r.: „Ostatecznie istnieje tylko bezinteresowne uczucie, tylko poczucie własnej wartości. Kto jego nie ma, ten nie odczuwa w sobie czegoś niezniszczalnego i wiecznego" ${ }^{50}$. W uzasadnieniu przeciwstawienia dwóch wizji świata: idealistycznej i materialistycznej - Eckart raczej nieudolnie odwoływał się do koncepcji jeszcze jednego filozofa niemieckiego, mianowicie do Arthura Schopenhauera. Do przekonania Eckarta trafiało - jak się wydaje - jego ujmowanie świata jako „woli i wyobrażenia” (Wille und Vorstellung). Za realny byt uznawał ten filozof jedynie przyrodę i jednostkę ludz-

osoby wierzącej w potęgę ludzkiej woli - został przez Eckarta zamieszczony w dramacie Heinrich der Hohenstaufe.

48 Eckart nawiązywał $\mathrm{w}$ tej kwestii do poglądów siedemnastowiecznego poety religijnego występującego pod pseudonimem Angelus Silesius. Zob. M. Plewnia, op. cit., s. 44; R. Lembert, op. cit., s. 17.

49 Zob. G.L. Mosse, Kryzys ideologii niemieckiej..., passim; idem, Die nationalisierung der Massen. Politische Symbolik und Massenbewegungen in Deutschland von den Napoleonischen Kriegen bis zum Dritten Reich, Frankfurt am Main 1976, passim.

50 Za: A. Rosenberg, Dietrich Eckart..., s. 33. 
ką, której egzystencja miała być zagrożona przez samounicestwienie ${ }^{51}$. Wobec nieuchronnej zagłady życiu może nadać sens tylko metafizyczna kontemplacja wyrażająca ucieczkę od ślepej woli rodzącej niepokój. W mniemaniu Eckarta ucieleśnieniem tej destruktywnej woli był nie kto inny, jak właśnie Żydzi, gdyż głosili oni „afirmację świata” skazanego na unicestwienie. Taki stosunek do świata miał zresztą stanowić warunek przetrwania tej nacji w warunkach braku własnej państwowości i diaspory wśród innych narodów. Jak widać, Eckart próbował nadać tzw. kwestii żydowskiej wymiar bardziej problemu filozoficznego niż rasowego, a tym samym odżegnywał się od haseł prymitywnej, sztampowej propagandy antysemickiej. Na marginesie warto dodać, że w znacznie mniej wysublimowany sposób ujmował owo zagadnienie Hitler.

Eckart rozpatrywał kwestię żydowską także jako problem o charakterze religijnym. Nie traktował go jednak jako najważniejszego aspektu swego antysemityzmu, a raczej jako jego dopełnienie. Nie zamierzał wszakże odrzucić tego niemal klasycznego - występującego od setek lat w Europie - sposobu ujmowania przyczyn i przejawów wrogości do Żydów. Prawdopodobnie wydawał się on Eckartowi na tyle społecznie nośny, bo zakorzeniony wśród Niemców, że był wart posługiwania się nim jako orężem ideologicznym. W tej dziedzinie mógł się wzorować - jak czyniło to zresztą przed nim wielu innych volkistów - na założeniach chrześcijańskiego antysemityzmu jeszcze z okresu średniowiecza. Przypomnę, że koronnym argumentem dawnych wrogów Żydów, służącym dyskryminowaniu, a nawet zwalczaniu tej ludności, był fakt ukrzyżowania przez nich Jezusa Chrystusa. Za wystarczający, choć nie zasadniczy dla rozwoju antysemityzmu, uważał ten obiegowy pogląd również Eckart. Na zebraniu NSDAP pod koniec listopada 1922 r. dowodził, że Syn Boży dlatego wyrzucił - według Biblii - żydowskich kupców ze świątyni, ponieważ ,jako pierwszy w pełni zrozumiał, czym naprawdę są Żydzi"s2. Rozwijając tę myśl, precyzował to, co już wcześniej starał się wykazać, mianowicie że są oni występni, żądni zysku, przekupni czy amoralni. Powtarzał zatem slogany powszechnie przyjmowane w propagandzie volkistowskiej. Skłonny był nawet bronić tezy (występującej też w innych przekazach antysemickich w Niemczech) o aryjskim pochodzeniu Chrystusa, byle tylko krytykować Żydów jako Jego przeciwników należących od odmiennej rasy. W koncepcjach Eckarta zasadniczą rolę odgrywała jednak nie kwestia „rasowego” pochodzenia Chrystusa, lecz dążenie do wykazania istotnych sprzeczności między religią Jego wyznawców i religią mojżeszową. Eckart pragnął nawet uchodzić (podobnie jak

51 Zob. A. Schopenhauer, Świat jako wola i przedstawienie, Warszawa 1994. Eckart zastąpił Schopenhauerowską ideę bytu w niewiedzy tezą ,świat jest moim marzeniem”. Zob. M. Plewnia, op. cit., s. 68; W. Grün, Dietrich Eckart als Publizist, München 1941, s. 43.

${ }_{52}$ Bayerisches Hauptstaatsarchiv München, Zespół Bayerisches Staatsministerium des Innern 81573, nfol. 
Rosenberg) za czołowego znawcę tej problematyki wśród nazistów ${ }^{53}$. Opierając się na poglądach volkisty o żydowskich korzeniach, powołanego już przeze mnie Ottona Weiningera, zarzucał twórcom Starego Testamentu „brak wiary w nieśmiertelność duszy”. W przekonaniu Eckarta religia żydowska była pozbawiona „metafizycznej tendencji”, która miała cechować Nowy Testament, czyniąc tym samym chrześcijan bardziej uduchowionymi i wierzącymi od Żydów. Dziennikarz ten wyznawał zasadę: ,Jaki człowiek, taki jego Bóg” ${ }^{54}$. W przeciwieństwie do religii żydowskiej wiara chrześcijańska miała się opierać na „głębokich treściach spirytualistycznych". Najbardziej oczywistym potwierdzeniem odmienności obu religii było według Eckarta zmartwychwstanie Chrystusa jako Mesjasza nieuznawanego przez Żydów. Z tego względu w toczącej się walce tych dwóch systemów religijnych ostateczne zwycięstwo powinno odnieść chrześcijaństwo. Zmartwychwstanie Syna Bożego dowiodło bowiem „absolutnej prawdziwości” tej religii oraz jej wyższości nad wiarą mojżeszową i każdą inną religią ${ }^{55}$. Poglądy Eckarta na temat obu religii odzwierciedlały jego wyżej wzmiankowane koncepcje afirmacji i zniszczenia świata. Jak wynika z wywodów powoływanych już biografów tego nazisty, w życiu prywatnym wcale nie był on gorliwym chrześcijaninem, lecz osobą raczej liberalnie nastawioną do spraw wiary.

Na osobne omówienie zasługuje jedno z ostatnich opracowań Eckarta, które ukazało się po raz pierwszy drukiem już po jego śmierci (1924), choć nie dlatego, że było ono rozprawą wnoszącą oryginalne spojrzenie na sprawy żydowskie. $\mathrm{Z}$ tego punktu widzenia raczej nie zawierało bowiem jakichś szczególnie nowatorskich ustaleń. Należy ponownie zaznaczyć, że pod wieloma względami zwyczajnie powielało ono hasła mieszczące się w kanonie volkistowskiego myślenia o Żydach, ale zarazem uzupełniało je o pewne dodatkowe „elementy poznawcze”, które mogły się wydawać nieco zaskakujące. Do przedstawienia założeń antysemityzmu zawartych w owym opracowaniu skłania przede wszystkim jego przewodnia problematyka wskazana już w tytule tej publikacji. Otóż Eckart za cel postawił sobie prześledzenie rozwoju bolszewizmu jako mu współczesnego zjawiska - którego przedstawiciele sprawowali przecież wtedy władzę w Rosji i próbowali rozszerzać komunistyczne wpływy na inne kraje - już od zamierzchłych czasów Mojżesza aż po okres rządów Włodzimierza I. Lenina ${ }^{56}$. Innymi

53 Obaj ideolodzy nazistowscy rywalizowali nawet między sobą o pierwszeństwo w dziedzinie religijnego uzasadniania antysemityzmu. Ostatecznie autorytetem w tej kwestii okazał się jednak Rosenberg. Szerzej o jego założeniach krytyki Żydów zob. M. Maciejewski, Od piwiarnianego klubu do organizacji wywrotowej..., s. 286 i n.

${ }_{54}$ A. Rosenberg, Dietrich Eckart..., s. 211.

55 M. Plewnia, op. cit., s. 143; R.M. Engelmann, op. cit., s. 68; J.H. Tyson, op. cit., s. 122.

56 D. Eckart, Der Bolschewismus von Moses bis Lenin. Zwiegespräch zwischen Adolf Hitler und mir, München 1924. Tytuł drugiego wydania (1925) brzmiał już tylko: Der Bolschewismus von seinen Anfängen bis Lenin. 
słowy, nazistowski publicysta upatrywał genezy i początków bolszewizmu w odległej starożytności, a nie w erze nowożytnej (od XVIII/XIX w.), jak zwykło się to ujmować w różnej proweniencji literaturze. Eckart stawiał w zasadzie znak równości między tzw. żydostwem i komunizmem, traktując to drugie zjawisko jako pochodną pierwszego, a nawet jako wytwór Żydów sprzed wielu stuleci. Nie mniej ważna - jako przesłanka omówienia publikacji o bolszewizmie - okazuje się także konstrukcja tego opracowania. Nie zostało ono bowiem napisane jako wykład poglądów samego Eckarta, ale przyjęło formę rozmów między nim i Hitlerem. Między innymi z tego powodu brak w literaturze jednomyślności w kwestii uznania Eckarta za jedynego autora rzeczonej publikacji ${ }^{57}$. Jak by nie było, w treści tego opracowania można dostrzec wyraźne odzwierciedlenie poglądów tego dziennikarza i niemal całkowitą zgodność opinii Hitlera $\mathrm{z}$ jego dywagacjami. Czy oznacza to, że powielał on jedynie koncepcje Eckarta? Nie ulega wątpliwości, że Hitler znany był w środowisku volkistowskim już na początku lat 20. ze swego zapiekłego antysemityzmu, a utwierdzał go w nim m.in. Eckart. Jak wiadomo, nie tylko na nim wzorował się Hitler. W każdym razie publikację o bolszewizmie można zakwalifikować jako interesujący przyczynek - choć tylko jeden z wielu - do poznania odnośnych zapatrywań Hitlera. Co nie mniej istotne, ze względu na temat niniejszego artykułu, rzeczone opracowanie jest jednym z nielicznych dowodów bezpośredniej wymiany opinii między nauczycielem Eckartem i jego uczniem Hitlerem. O wpływie pierwszego z nich na drugiego jednoznacznie świadczą przynajmniej niektóre enuncjacje wodza NSDAP przytoczone przez Eckarta.

Osobiste oddziaływanie tego publicysty na koncepcje Hitlera ujawniło się w jego wypowiedziach o religii żydowskiej. Przede wszystkim starał się on wykazać brak religijnego charakteru wyznania mojżeszowego w przeciwieństwie do chrześcijaństwa, którego zresztą również nie cenił jako religii i które (zwłaszcza katolicyzm) już w okresie Trzeciej Rzeszy zaczął zwalczać, dążąc do jego likwidacji. Przed 1933 r. nie eksponował jednak swej niechęci do chrześcijaństwa, by nie narazić się szerszym kręgom niemieckiego społeczeństwa. Hitler stawiał w omawianej publikacji retoryczne według niego pytanie, czy za wyraz religii, czy tylko jej surogatu, można uznać takie typowe dla Żydów cechy, jak obłuda, krętactwo, pycha, skłonność do oszustwa, a nawet do morderstw ${ }^{58}$. Nietrudno się domyśleć, jaka była odpowiedź przywódcy NSDAP. W swych dywagacjach posuwał się on jeszcze dalej, formułując wręcz absurdalne tezy. I tak wskazywał na „zażydzenie”

57 Zob. M. Plewnia, op. cit., s. 108; E. Nolte, Eine frühe Quelle zu Hitlers Antisemitismus, „Historische Zeitschrift“ 1961, Nr. 3, DOI: https://doi.org/10.1524/hzhz.1961.192.jg.584, s. 604605; A. Tyrell, Vom Trommler zum Führer. Der Wandel von Hitlers Selbstverständnis zwischen 1919 und 1924 und die Enticklung der NSDAP, München 1975, s. 194.

58 D. Eckart, Der Bolschewismus von Moses..., s. 45. Podobnie Hitler wypowiadał się w Mein Kampf (op. cit., s. 335 i n.). 
chrześcijaństwa przez wpojenie jego wyznawcom - za sprawą św. Pawła - zasad wolności, równości i braterstwa, które miały znaleźć się u podstaw współczesnego bolszewizmu, a przed nim - rewolucji francuskiej u schyłku XVIII w. Według inspirowanego przez Eckarta Hitlera za hasłami czasowo rozciągniętego przez niego do bardzo odległej przeszłości komunizmu stali zatem Żydzi, podobnie jak w ogóle za ideami socjalizmu czy liberalizmu. Podobnie tłumaczył on wpływ Żydów na oblicze chrześcijaństwa, choć równocześnie przeciwstawiał sobie obie religie jako zasadniczo odmienne. Oparta na rzekomo wspólnych celach politycznych wymierzonych w porządek i harmonię świata symbioza żydostwa i chrześcijaństwa miała datować się już od czasów Mojżesza. Jako pierwszy w dziejach „bolszewik” dokonał on bowiem „rewolucyjnego zamachu” żydowskiego motłochu (Pöbelvolk) na rządzącą warstwę w Egipcie, przeprowadzonego pod hasłem: „Proletariusze wszystkich krajów, łączcie się" 59 . W ten sam sposób Żydzi mieli „perfidnie zadziałać" podczas rewolucji w Rosji w 1917 r. i rok później w Niemczech. Zawsze chodziło im głównie o to, by poprzez wysuwanie postępowych haseł zaspokajać ,żądzę władzy motłochu", a równocześnie samemu objąć rządy nad nim ${ }^{60}$. Zgadzający się $\mathrm{w}$ tej $\mathrm{i} \mathrm{w}$ innych kwestiach z Hitlerem, przytakujący jego mętnym wynurzeniom Eckart postulował w związku z tym likwidację synagog i szkół żydowskich jako „wylęgarni” dążeń Żydów do zapanowania nad światem. Obaj naziści obawiali się jednak nieskuteczności takich działań przeciwko Żydom. W swojej rozmowie wyrazili pogląd, że zwalczanie ,żydowskiego ducha" będzie niezwykle trudnym zadaniem ze względu na jego wszechobecność. Według wspomnianego Noltego przedstawione koncepcje antysemickie Eckarta i Hitlera nosiły ślady wpływu dwóch antyrewolucyjnych i konserwatywnych nurtów myśli europejskiej XIX w.: chrześcijańsko-spirytualistycznego (Joseph de Maistre i Louis de Bonald) oraz antychrześcijańsko-naturalistycznego (Arthur de Gobineau i Georges de Lapouge) ${ }^{61}$. Można by polemizować z tym niemieckim uczonym, nie sposób bowiem przyjąć za pewnik pełnej znajomości poglądów tych intelektualistów przez obu nazistowskich-ideologów. Z kolei Werner Maser wskazuje w tym kontekście na inspiracje ze strony takich volkistowskich antysemitów, jak Otto Hauser, Henry Ford, Werner Sombart czy Roger Gougenot des Moussaux ${ }^{62}$. W tym przypadku także można co najwyżej mówić o jakichś pośrednich zapożyczeniach.

Nie ulega wątpliwości, że Hitler bezpośrednio wzorował się w swym antysemityzmie m.in. na Eckarcie. To on w dużej mierze uświadomił mu zależności mię-

59 W uzasadnieniu tej tezy Hitler powoływał się na biblijny opis ucieczki Żydów z Egiptu według II Księgi Mojżesza (Exodus 12,38) i Proroctwa Izajasza (19,2-3). Zob. Pismo Święte Starego $i$ Nowego Testamentu, według thumaczenia ks. J. Wujka poprawionego przez ks. W. Lohna, Poznań 1965, s. 84, 895.

60 D. Eckart, Der Bolschewismus von Moses..., s. 46.

61 E. Nolte, Der Faschismus in seiner Epoche..., s. 405; idem, Eine frühe Quelle..., s. 590.

${ }^{62}$ W. Maser, op. cit., s. 88-89. 
dzy prastarym „żydostwem” a rozwojem postępowych doktryn z komunizmem na czele czy też wpływ Żydów na założenia myśli chrześcijańskiej. Uczulił go również na problem „zła” mającego wynikać z amoralnej, zaborczej i bezwzględnej natury Żydów. Pouczał wreszcie Hitlera o skutkach nieustannej walki ze sobą „,dwóch światów": materialistycznego (żydowskiego) i idealistycznego (aryjskiego). Eckart nie wpoił natomiast Hitlerowi przywiązania do wartości rasowych, gdyż sam nie był typowym rasistą, czyli wyznawcą antropologicznych teorii, którym z kolei hołdował przywódca nazistów. Warto wskazać, że zanim Hitler stał się rasistą, był już zapiekłym antysemitą ${ }^{63}$. W kwestiach rasowych mógł on za to wzorować się na innych niż Eckart ideologach volkistowskich. Dla Eckarta ważniejsze od kwestii czysto rasowych w odniesieniu do Żydów były zagadnienia etyczno-obyczajowe i religijno-kulturowe. Jego antysemityzm wydaje się nieco bardziej „humanitarny” i nieco bardziej „subtelny” od antysemityzmu Hitlera. W okresie samych początków kariery politycznej Hitlera taki niezbyt agresywny w swej wymowie sposób postrzegania Żydów przez Eckarta (a także niektórych innych antysemitów niemieckich) mógł jednak okazać się przydatny dla wodza NSDAP. Wskutek tego zyskał on bowiem ogólne podstawy dla kształtowania się własnego antysemityzmu. Wydaje się bezsporne, że poglądy Eckarta w sprawach Żydów mogły stanowić dla Hitlera punkt wyjścia w tej dziedzinie - wprawdzie nie jedyny, ale zapewne ważny, gdyż mający spory wpływ na wyrobienie sobie przez niego negatywnych opinii o tej nacji. Nie powinno się jednak przeceniać znaczenia koncepcji Eckarta jako mentora Hitlera. Powtórzę raz jeszcze: przecież nie tylko ten volkista w jakimś stopniu oddziaływał na zapatrywania wodza NSDAP. W swym antysemityzmie Hitler poszedł zresztą znacznie dalej niż Eckart. W latach 1933-1945 tzw. kwestia żydowska nie ograniczała się dla przywódcy nazistów i kanclerza Trzeciej Rzeszy jedynie do teoretycznych dywagacji, lecz znalazła swój wyraz w sferze praktycznej. Nigdy się nie dowiemy, jak Eckart oceniłby podjęte przez ówczesne władze niemieckie restrykcje i represje wobec Żydów. Można jednak przypuszczać, że nie byłby zwolennikiem tak bezwzględnego i okrutnego traktowania ich na obszarach Europy.

\section{BIBLIOGRAFIA}

Auerbach H., Hitlers politische Lehrjahre und die Münchener Gesellschaft, „Vierteljahrshefte für Zeitgeschichte“ 1977, Nr. 1.

Böhme H., Gedichte des Volkes. Dietrich-Eckat-Band (Vom Jahr 1 bis zum Januar 5 des Dritten Reiches), München 1938.

Böhme H., Rufe in das Reich. Die heldische Dichtung von Langemarck bis zur Gegenwart, Berlin 1934.

${ }^{63}$ Jednym z pierwszych badaczy, który zwrócił na to uwagę, był Eberhard Jäckel w wydanej w Polsce książce Hitlera pogląd na świat (Warszawa 1973). Według niego i innych autorów antysemityzmem Hitler przesiąknął jeszcze przed I wojną światową. Zob. m.in. A. Bullock, Hitler. Studium tyranii, Warszawa 1970, s. 47. 
Bullock A., Hitler. Studium tyranii, Warszawa 1970.

Bullock A., Hitler i Stalin. Żywoty równoległe, Warszawa 1994.

Craftword P., Dietrich Eckart. Master of the Occult and Hitler's Mentor, London 2013.

Eckart D., Der Bolschewismus von Moses bis Lenin. Zwiegespräch zwischen Adolf Hitler und mir, München 1924.

Eckart D., Der Heilige und der Narr. Gedanken über das Chaos unserer Zeit, „Unser Vaterland“ 1916, Nr. 1.

Engelmann R.M., Dietrich Eckart and the Genesis of Nazism, Ann Arbor 1971.

Engert R., Henrik Ibsen als Verkünder des Dritten Reiches, Leipzig 1921.

Euringer R., Dietrich Eckart. Leben eines deutschen Dichters, Hamburg 1935.

Feder G., Das Programm der NSDAP und seinen weltanschaulichen Grundgedanken, München 1933.

Franz-Willing G., Die Hitlerbewegung. Der Ursprung 1919-1922, Hamburg-Berlin 1962.

Gilbhard H., Die Thule-Gesellschaft. Vom okkulten Mummenschanz zum Hakenkreuz, München 1994.

Goodrick-Clarke N., Okultystyczne źródła nazizmu. Tajne kulty aryjskie oraz ich wptyw na ideologię nazistowska. Ariozofowie z Austrii i Niemiec 1890-1935, Warszawa 2001.

Görlitz W., Quint H.A., Adolf Hitler. Eine Biographie, Stuttgart 1953.

Grün W., Dietrich Eckart als Publizist, München 1941.

Hamann B., Wiedeń Hitlera. Lata nauki pewnego dyktatora, Warszawa 2013.

Hanfstaengl E., Zwischen Weissem und Braunem Haus. Memoiren eines politischen Aussenseiters, München 1970.

Heiden K., A History of National Socialism, London 1934.

Hitler A., Mein Kampf, München 1933.

Hohoff C., Flügel der Zeit. Deutsche Gedichte 1900-1950, Frankfurt am Main 1956.

Jäckel E., Hitlera poglad na świat, Warszawa 1973.

Kershaw I., Hitler. 1889-1935. Hybris, Poznań 2001.

Kershaw I., Mit Hitlera. Wizerunek a rzeczywistość III Rzeszy, Zakrzewo 2009.

Lauryssens S., Człowiek, który wymyślit Trzecia Rzeszę, Wrocław 2000.

Lembert R., Dietrich Eckart. Ein Künder und Kämpfer des Drittes Reiches, München 1934.

Luedecke K., I Knew Hitler, London 1938.

Maciejewski M., O przesłankach i źródłach światopoglądu Adolfa Hitlera, „Studia nad Autorytaryzmem i Totalitaryzmem" 2013, t. 35, z. 1.

Maciejewski M., Od piwiarnianego klubu do organizacji wywrotowej. Nazizm w latach 1919-1924, Torun 2005.

Maciejewski M., Wiedeński okres w życiu Adolfa Hitlera w ujęciu Brigitte Hamann i Augusta Kubiz$k a$, ,Studia nad Autorytaryzmem i Totalitaryzmem” 2017, t. 39, z. 3.

Maciejewski M., Wódz i jego drużyna. Początki kształtowania się władzy i autorytetu Adolfa Hitlera wśród nazistów, „Studia nad Faszyzmem i Zbrodniami Hitlerowskimi” 2010, t. 32.

Maciejewski M., Z nienawiści do Żydów. Rozważania nad głównym komponentem światopogladu Adolfa Hitlera, [w:] Medycyna w cieniu nazizmu, red. M. Michalak, K.B. Głodowska, Poznań 2015.

Maser W., Der Sturm auf die Republik. Frühgeschichte der NSDAP, Stuttgart 1973.

Moeller van den Bruck A., Das dritte Reich, Hamburg 1931.

Mosse G.L., Die nationalisierung der Massen. Politische Symbolik und Massenbewegungen in Deutschland von den Napoleonischen Kriegen bis zum Dritten Reich, Frankfurt am Main 1976.

Mosse G.L., Kryzys ideologii niemieckiej. Rodowód intelektualny Trzeciej Rzeszy, Warszawa 1970.

Nolte E., Der Faschismus in seiner Epoche. Die Action française. Der italienische Faschismus. Der Nationalsozialismus, München 1962.

Nolte E., Eine frühe Quelle zu Hitlers Antisemitismus, „Historische Zeitschrift“ 1961, Nr. 3, DOI: https://doi.org/10.1524/hzhz.1961.192.jg.584. 
Phelps R.H., "Before Hitler Came": Thule Society and Germanen Orden, "Journal of Modern History" 1963, No. 3, DOI: https://doi.org/10.1086/243738.

Phelps R.H., Theodor Fritsch und der Antisemitismus, „Deutsche Rundschau“ 1961, Nr. 5.

Pismo Święte Starego i Nowego Testamentu, według tłumaczenia ks. J. Wujka poprawionego przez ks. W. Lohna, Poznań 1965.

Plewnia M., Auf dem Weg zu Hitler. Der völkischer Publizist Dietrich Eckart, Bremen 1970.

Reich A., Dietrich Eckart - ein deutscher Dichter und Vorkämpfer der völkischen Bewegung, München 1933.

Ribadeu-Dumas F., Tajemne zapiski magów Hitlera, Warszawa 1992.

Rose D., Die Thule-Gesellschaft. Legende - Mythos - Wirklichkeit, Tübingen 2000.

Rosenberg A., Blut und Ehre. Ein Kampf für deutsche Wiedergeburt. Reden und Aufsätze 19191933, München 1939.

Rosenberg A., Dietrich Eckart. Ein Vermächtnis, München 1935.

Schopenhauer A., Świat jako wola i przedstawienie, Warszawa 1994.

Schubert G., Die Anfänge der nationalsozialistischen Aussenpolitik 1919-1923, Berlin 1961.

Sebottendorff R. von, Bevor Hitler kam. Urkundliches aus der Frühzeit der nationalsozialistischen Bewegung, München 1934.

Spengler O., Der Untergang des Abendlandes. Umrisse einer Morphologie der Weltgeschichte, Bd. 1-2, München 1922-1923.

Stegmann D., Zwischen repression und Manipulation. Konservative Machtteilen und Arbeiter- und Angestelltenbewegung 1910-1918, „Archiv für Sozialgeschichte“ 1971, Bd. 12.

Tyrell A., Vom Trommler zum Führer. Der Wandel von Hitlers Selbstverständnis zwischen 1919 und 1924 und die Enticklung der NSDAP, München 1975.

Tyson H., Hitler's Mentor: Dietrich Eckart. His Life, Time and Millieu, Bloomington 2008.

Unger E., Das Schrifttums des Nationalsozialismus von 1919 bis. 1. Januar 1934, Berlin 1934.

Valode P., Hitler i tajne stowarzyszenia, Warszawa 2010.

Zoller A., Hitler privat. Erlebnisbericht einer Geheimsekräterin, Düsseldorf 1949.

\section{SUMMARY}

The article analyzes the significance and the role played by Dietrich Eckart - a German poet and a political writer from Munich - for the development on Adolf Hitler's early political career and for the shaping of political views of the future leader of the Third Reich. As the author concludes, Eckart's influence on Hitler's political activity and ideas during the first few years after World War One would be difficult to overestimate. Eckart proved himself then to be one of the most important mentors of Hitler - as his teacher, adviser and supporter who made it possible for the latter to make valuable and useful contacts in nationalist intellectual, military and industrial circles of Bavaria. To a significant degree, Hitler borrowed from Eckart, who was an ardent Anti-Semite, a number of arguments against Jews and accusations leveled against them. Hitler also partly based his criticism of the democratic system in Germany after World War One on Eckart's views which were sharply hostile towards the Weimar Republic. Eckart was one of the very few people from Hitler's closest ranks towards whom the future leader of Germany managed to show - in Mein Kampf - gratitude and respect for the former's support and aid during the first few years of the existence of the Nazi organization.

Keywords: Dietrich Eckart; Adolf Hitler; national socialism; anti-semitism 


\section{STRESZCZENIE}

Artykuł dotyczy znaczenia i roli poety i publicysty niemieckiego z Monachium - Dietricha Eckarta - dla rozwoju wczesnej kariery politycznej Adolfa Hitlera i kształtowania się politycznych poglądów przyszłego wodza Trzeciej Rzeszy. Jak wynika z wywodów autora, wpływ Eckarta na polityczną działalność i zapatrywania Hitlera w kilku pierwszych latach po zakończeniu wojny światowej był trudny do przecenienia. Eckart okazał się wtedy jednym z najważniejszych mentorów Hitlera - jako jego nauczyciel, doradca i poplecznik, który umożliwił mu nawiązanie cennych i pożytecznych kontaktów w nacjonalistycznych środowiskach intelektualnych, wojskowych i przemysłowych w stolicy Bawarii. W znacznej mierze od Eckarta, zagorzałego antysemity, Hitler zapożyczył wiele argumentów przeciwko Żydom i wymierzonych w nich oskarżeń. Częściowo na wrogich tzw. republice weimarskiej poglądach Eckarta oparł także swoją krytykę demokratycznego ustroju Niemiec po I wojnie światowej. Eckart był jedną z niewielu osób z najbliższego otoczenia Hitlera, wobec których przyszły wódz Niemiec zdobył się na okazanie w Mein Kampf wdzięczności i szacunku za wsparcie i pomoc ze strony tego publicysty w kilku pierwszych latach działalności organizacji nazistowskiej.

Słowa kluczowe: Dietrich Eckart; Adolf Hitler; narodowy socjalizm; antysemityzm 